\title{
Biologische : opmerkingen uit de Diergaarde van het Kon. Zoologisch Genootschap „Natura Artis : Magistra” \\ DOOR
}

\author{
A. F. J. PORTIELJE, \\ Inspecteur over de levende have.
}

(Met plaat III).

Ardea goliath Cretschm.

Sedert 1908 heeft een op 24 April 1904 aangekocht paar Reuzenreigers jaarlijks gebroed en gewoonlijk 3, een enkele maal ook eens 4 jongen per broedsel grootgebracht. Dat door dit op volle kleur gekocht paar eerst in Juli 1908 aanstalten tot nestelen gemaakt werd, kan een gevolg zijn geweest van het feit, dat de vogels toen eerst voldoende geacclimatiseerd waren en mede onder invloed van een vrij warmen voorzomer tot hun volle geslachtsvermogen zijn geraakt. Of wel is dit aanvankelijk succes te danken geweest aan het feit, dat ze zich toen eerst volkomen. "veilig" hebben gevoeld in hun aan een druk begaan hoofdpad gelegen perk. Misschien echter hebben zoowel physische als psychische factoren beiden hun rol gespeeld. Opmerkelijk is ook het verschijnsel dat de vogels, toen de groote poging eenmaal gewaagd was, het in volgende jaren niet bij een of twee broedșels per jâr lieten blijven, maar - in tegenstelling tot onze inlandsche en andere arctische vogels - zonder zich aan den loop der seizoenen te storen, op zeer verschillende tijden eieren hebben gelegd en trouw bebroed. Zoo werd ook in December (bij 3\% Fahr. zelfs eens) soms nog genesteld; dat van deze legsels dan tengevolge van lage temperatuur en ongunstige weersgesteldheid niets terecht kwam behoeft geen verder betoog.

Aangezien iets dergelijks hier ook bij Pyrrherodias manillensis kon worden waargenomen, van welke vogels b. v. in 1918 drie broedsels werden verkregen, waarvan het laatste echtër door de intredende koude (26 Sept. werd het eerste jong geboren) mislukte, is wellicht de veronderstelling niet geheel te verwerpen, dat bij tropische vogels niet van een bepaalden broedtijd - althans niet van ten hoogste twee broedsels - sprake behoeft te zijn, maar dat zich in de tropen het geval kan voordoen dat zoolang het jaàrgetijde gunstig is - in onze Oost b. v. tijdens den drogen moesson - broedsel na broedsel wordt grootgebracht.

Bij de copulati e hurkt het $ᄋ$ op de "hielen" - dus in het voetwortelgewricht - neer; het $\sigma^{\top}$ grijpt met den snavel het $q$ bij den hals, het $q$ spreidt de vleugels eenigszins uit, waarna het $\sigma^{7}$ zich op den rug van het $q$ staande houdend, het achterlichaam zijwaarts omlaag, en de cloaca-monding tegen die van het $o$ brengt.

Aanvankelijk legden de vogels de eieren in het buitenperk. Ze werden dan echter met hunne eieren ter wille van rust en beveiliging tegen regen en koude in hun nachthok gebracht en zoolang opgesloten gehouden tot zekerheid verkregen wàs, dat ze hun nestelen, bijleggen en broeden op de door ons gewenschte plaats zouden voortzetten en voleinden.

$\mathrm{Na}$ twee malen achtereenvolgens hier toe te zijn gedwongen, bleek het ouderpaar voor 
't vervolg zich te hebben leeren schikken en - zij 't dan ook niet met „inzicht" - wat van hen ook niet te verlangen zou zijn - het rustig en regenvrij nachthok te verkiezen boven een meer natuurlijke broedplaats onder den open hemel. Hier heeft dus weer een "leeren uit ervaring" tot "gewoontevorming" bijgedragen; hebben verworven associaties het ge ërfd instinct gewijzigd.

Tegen nestelen op den vlakken grond bleek bij ons paar A. goliath geen overwegend bezwaar te bestaan; weliswaar kon hun in het nachthok geen nestel-boom gegeven worden, maar zoowel de omstandigheid dat onze inlandsche A. cinerea, hoewel bij voorkeur koloniegewijs in boomen broedend, soms ook afzonderlijk in 't rietland nestelen wil, als ook het feit dat onze Reuzenreigers zij' 't ook noodgedwongen uit eigen' beweging in 't buitenperk op den grond zijn begonnen te nestelen - terwijl inlandsche Ooievaars zich nimmer zonder de gebruikelijke verhooging van eenig staketsel tot broeden lieten bewegen - wettigen het vermoeden, dat A. goliath in de vrije natuur ook in 't rietbosch of op moerasgrond nestelen zal.

Als nestel-materiaal bezigden onze vogels voornamelijk door hen geplukte stengels en bladen van Bambusa metake en voorts ook veel stroo, terwijl takken, vooral grootere, verworpen werden, wat ook weer wijst op een niet in 't geboomte broeden.

Beide ouders bouwen aan 't nest, met dien verstande evenwel, dat het $\sigma$ meer in 't bijzonder aansleept - daarbij echter volstrekt niet, zooals altijd voor de Ardeidae wordt opgegeven, het materiaal alleen en uitsluitend overlangs en nimmer overdwars in den bek dragend - terwijl het $q$ voor de rangschikking en den aanleg van 't nest zorgdraagt.

$\mathrm{Bij}$. het broeden lossen $\sigma$ en $q$ elkaar, af, doch voor de verwarming der kuikens zorgt alleen het $o$, terwijl het $\sigma^{\prime}$ het $q$ dan visch op 't nest brengt' en zich met' de bewaking van het nest belast.

Het legsel bestaat uit 3 tot 5 eieren van bleekblauwe kleur, gewoon eivormig en metend $67 \times 4 \%$ m.m.

Ze worden om de twee dagen gelegd; de kuikens komen eveneens twee dagen na elkaar uit, zoodat de duur der bebroeding - berekend als de tijd welke onderscheidenlijk verloopt tusschen het gelegd worden en uitkomen van elk ei- 30 dagen bedraagt, welke bebroedingstijd dus langer duurt dan die van A. cinerea, die op 28 dagen gesteld moet worden.

De kuikens vertoonen het gewone reiger-donskleed van lange, grauw-witte en op de bovendeelen eenigszins vaalbruin getinte plumae. Op den kop heeft A. goliath ze verlengd tot een vervaarlijke „kuif". "Washuid, keel en voorzijde van den hals tot in de kropstreek toe zijn naakt en groenachtig van kleur.

Als ietwat gewaagde onderstelling moge hier de meening geopperd worden, dat dit eigenaardig woest uitziend donskleed - zoo geheel verschillend van dat der Ciconidae - wellicht min of meer als "afschrikmiddel" werkt, mede in verband met het feit dat de kuikens reeds in het aangepikte ei, bij aanraking daarvan, of wanneèr de moeder zich op de eieren beweegt, luid blazen, en eenmaal uitgerust op 't nest liggend, bij naderbij komen van vreemden en bij aanraking terstond de donsveeren en den "kuif" opzetten, om eveneens blazend kop en hals omhoog te heffen, welke bewegingen - niet aangeleerd of hoe ook verworven als ze zijn - moeten neerkomen op een cleronome (Ziegler) gecompliceerde reflex, een soort verdedigings-instinct wellicht:

Bij nadering der ouders evenwel blijwen de jongen stil liggen of wel - hongerig heffen ze als instinctmatige reactie op het lokkend geluid, dat de voerensgezinde ouders bij ' $t$ betreden van het nest laten hooren, koppen en halzen omhoog om instede van' het voornoemd geblaas een geheel ander, stootend en kokkerend geluid te maken.

De jongen liggen steeds onder de moeder, en worden nimmer, zooals dit bij de Kraanvogels op meer gevorderden leeftijd gebeurd naast het moederlichaam onder de vleugels verwarmd of zelfs op den rug gedragen. Beide ouders voederen na den eersten dag met voorverteerde en op het nest uitgebraakte visch, waarbij de jongen dan zoogezegd kokkerend de kopjes opheffen; doch geen moeite in ' $t$ werk stellen om het voedsel uit den snavel der ouders op te vangen. 
Hierop schijnt onder de Ardeidae Botaurus stellaris een uitzondering te maken, van welke soort door Steenhuizen en mij kon worden waargenomen dat de kuikens niet alleen - als alle Ardeidae en Ciconidae - den geërfden àanleg bezitten om het uitgebraakte voer zonder vóórpikken der ouders van den nestrand op te nemen, doch deze cleronome reflex nog door eene ambiontische associatie gewijzigd toonden, geleerd als ze .blijkbaar hadden om niet te wachten tot het voer op het nest lag, doch het terstond uit den voerenden snavel op te vangen en zelfs hunne wijdgesperde snaveltjes orn de zich openende oudersnavel heen te klemmen.

of zou misschien toch ook deze gecompliceerde beweging der jonge Botaurus stellaris niet eene "aangeleerde" zijn, maar eveneens een aangeboren gecompliceerde reflex, een instinctmatige beweging dus, zooals wij die kennen van de jongen van Phalacrocorax, welke van stonde af aan hun snavel en den geheelen kop zelfs, in den ouderlijken snavel steken om het voorverteerde voedsel bij het uit de krop opbraken reeds in ontvangst te nemen? En zou dan - om met 0 . Heinroth te spreken - waar een gelijk of gelijksoortig gedrag bij verschillende diere n waargenomen wordt een aanwijzing kunnen liggen naar het bestaan van eene, zij. 't ook in ver'verleden tijd liggende, nauwere verwantschap, en de ethologie hier een weliswaar meest wel zeer onzekere en gevaarlijke weg wijzen bij de oplossing van phylogenetische vragen?

Hoe dit ook zij, bij onze jonge Goliathreigers noch ook bij de eveneens in „Artis" regelmatig broedende Ardea cinerea, Pyrrherodias manillensis en Ciconia ciconia mochten wij ooit iets van de merkwaardige wijze van voedselopname gewaar worden, die door Steenhuizen en mij in Mei 1913 op de Ankeveensche plassen bij het toen voor de eerste maal in de natuur gephotographeerde Roerdompen-nest van de Botaurus-kuikens kon worden opgemerkt.

Wat nu den verderen opgroei der kuikens van Ardea goliath betreft nog het volgende. Van een drenken der kuikens, zooals dit soms, op zeer warme dagen althans, bij Ooievaars op het nest kon worden waargenomen (zie Ardea III, $N^{\circ} .4$ en IV, $N^{\circ} .1$ en 2) hebben wij bij Ardea goliath nimmer iets bemerkt. Zes weken na de geboorte ongeveer breken de eerste pennae door; zooals gewoonlijk de bij den eersten rui niet uitvallende slag- en stuurpennen het eerst, daarna de contour-veeren aan hals en rug, en met drie maanden ongeveer vertoonen de jongen een vaalbruin jeugdkleed, getemperd door grijsblauwe vlekken op de topeinden der vleugel- en rugdekveeren en lichtelijk geschakeerd door witte veer-rijen aan de voorzijde van den hals. Langen tijd nog blijven er donsveeren, met name op de kruin, tusschen de contour-veeren aanwezig.

Gedurende de drie-weeksche donskleed-periode blijven de jongen plat op het nest liggen - zoo gezegd alleen den kop heffend - daarna, ongeveer gelijktijdig met het doorkomen der dekveeren zijn ze eerst in staat zich op de "hielen" op te richten en na \pm 6 weken eveneens op de "hielen" te kruipen. De jongen blijven dus vergeleken met andere Ardeidae lang op het nest. (Van A. cinerea, Pyrrherodias purpurea en P. manillensis toch is ons bekend dat de kuikens ongeveer een maand op het nest vertoeven, terwijl door Steenhuizen en mij bij een nest van Botaurus stellaris in de Ankeveensche plassen kon worden waargenomen, dat de jongen bij onraad reeds na 12 dagen van het nest klauteren). Na 3 maanden ongeveer, wanneer het jeugdkleed vrijwel gereed is gekomen, worden ook de eerste vliegbewegingen gemaakt.

De in voorjaar of zomer geboren jongen houden hun jeugdkleed den winter door tot den eersten rui, welke gelijk met die der ouders in Juli-Augustus plaats grijpt. Dan krijgen ze hun een-jarigkleed, slechts weinig van het jeugdkleed verschillend, donkerder van tint en scherper geschakeerd door het wit der halsveeren. Bij den tweeden rui, in het daaropvolgend jaar dus, en bijgevolg tweejarig kleed kleuren de jonge vogels geheel op, en krijgen ze de verlengde sierveeren van den volwassen vogel aan hals en voor-rug.

\section{Pseudogeranus leucauchen Temm.}

Een 13 Sept. 1006 op kleur aangekocht paar Witnekkraanvogels verrastte ons na vier jaren met zijn eerste broedsel en heeft sindsdien verscheidene malen met succes jongen grootgebracht; aanvankelijk drie malen slechts één, in volgende jaren echter regelmatig twee ( $\left.\sigma^{x}-O\right)$ kuikens, het normale legsel bij alle Gruidae. Omstreeks half Mei wordt de paartijd ingeleid door de bekende sierlijke en luidruchtige paringsspelen. Het $\sigma^{t}$ opent de huwelijksplichten met een voorspel en wel door bijwijlen imponeerend voor het $q$ heen en. weer te schrijden, pronkend met opgezette sierveeren, fier gekromden hals en een "verhoogden blos" over de naakte huiddeelen van den kop. Af en toe geeft hij zijn gemoed lucht in een plotseling trompetgeluid, waarmee dan het overigens ingetogen al zijn bewegingen ontwijkende $O$ instemt, eveneens trompetterend en met rhytmische stooten den klaroen van het $\sigma^{\top}$ begeleidend. 
Op stille uren van morgen en voor-avond meest - de eigenlijke "Balzzeit" - konden wij den eigenaardigen kraanvogeldans waarnemen; in hoofdzaak door het $\sigma^{7}$ uitgevoerd, dat allerlei speelsch-statige passen afgewisseld door uitgelaten sprongen ten beste geeft, een en ander onder herhaalde, diepe buigingen en bekoorlijk vertoon van vleugelspreiden.

Het $\circ$, immer nog ingetogen den $0^{t}$ uit den weg gaande, beantwoord diens herhaalde liefdesbetuigingen aanvankelijk slechts met een zacht-koerend geluid van instemming; totdat zij ten slotte in 't voetwortelgewricht neerhurkend met half geopende vleugeis, door den haar bij den hals vastgrijpenden en op den rug springenden $\sigma^{t}$ in enkele minuten bevrucht wordt. De paring wordt dan besloten met een eendrachtig aangeheven trompetgeschal.

Door de naburige kraanvogels - de na-verwante soorten althans - wordt op alle trompetteren van het paar immer spontaan geantwoord, welke instemming echter niet zoozeer van sexueelen dan wel van socialen aard mag worden geacht. Evenals de lok- en waarschuwingsroepen en de alarmkreten van in troepen de takken afreizende of gemeenschappelijke vluchten uitvoerende vogels komt ook dit wederzijds aunroepen der kraanvogels neer op een collectieve gemoedsuiting, waarin een primitief saamgehoorigsheidgevoelen instinctmatig geuit wordt.

Genesteld wordt aan den waterkant; $\sigma^{x}$ en $q$ dragen beiden stroo uit het nachthok aan. Na eenigen tijd worden met drie dagen tusschentijd de beide ei eren gelegd, die toegespitst eivormig zijn en op' olijfgroenen in 't bruingele trekkenden ondergrond onregelmatig bruingevlekt, in dier voege dat naar den top toe de vlekken dichter opeen liggen en daar veelal een bruine poolvlek vormen. De doffe schaal is stevig en korrelig van structuur, de afmetingen bedragen $93 \times 56 \mathrm{~m} . \mathrm{m}$.

Beide vogels broeden afwisselend. De bebroedingstijd bedraagt 30 dagen. Van nu af aan schijnt het $q$ meer in 't bijzonder als omzichtig toeziende moeder in de onmiddellijke nabijheid der kuikens te blijven, terwijl de $\sigma^{x}$ als strijdlustig bewaker van den huwelijksschat optreedt, door voortdurend plechtstatig langs de hekken schrijdend de naburige vogels op afstand te houden. De haan - althans bij ons paar - belast zich ook in hoofdzaak met het aanbrengen van voedsel.

De kuikens laten zich als echte "nest-vlieders" kennen. Ze blijven hoogstens een däg op 't nest liggen, on dan terstond met de ouders mede te loopen, die hen echter bij tijd en wijle weer op 't nest terugvoeren om ze te koesteren. Beide ouders - in tegenstelling tot de Ardeidae - nemen de jơngen aarvankelijk onder, later terzijde van 't lichaam onder de vleugels, of zelfs wel op den rug, welk laatste instinct (want hier is blijkbaar geen verworven "gewoonte" in 't spel) zoowel bij Gruidae als bij Cygnidae voorkomt.

Het donskleed is aanvankelijk geelachtig wit; op vleugels, rug en kruin echter treedt al spoedig een bruine verkleuring op, aangezien daar ter plaatse met drie weken de eerste bruin-getinte pennen van het jeugdkleed komen doorbreken. In den nu volgenden tijd zien de potsierlijk met de behoedzaam rondstappende steltpooten van het ouderpaar mee-tippelende kuikens er allerparmantigst uit, op hun nog onevenredig korte en dikke waadpootjes; en met hun kortgesnaveld kopje op den aankomenden, maar nog alle sierlijkheid missenden kranenhals, soms "neuswijs" in de lucht (zie bijgaande foto). Beide ouders - bij ons paar echter voornamelijk het $\sigma^{7}$, dat het ijverigst voerde, terwijl het $o$ den kuikens soms wel de lekkere beetjes voor den snavel wegsnoepte - belasten zich met de voedering, en wel in dier voege, dat ze hunne jongen van stonde af aan tot pikken opwekken. Telkens komt zoogezegd vooral het $\sigma^{\gamma}$ - met een gevangen vlieg of eenig ander insect, of wel met van Artis-wege verstrekte mierenpoppen, meelwormen of fijn-gehakte visch in den snavel naar de kuikens toe, het hapje schijnbaar onhandig "serveerend" want latende het - onder 't maken' van een koerend geluid - vlak voor het kuiken op den grond vallen. Pikt nu 't jong niet terstond toe, zoo wordt het hapje opnieuw opgenomen en aangeboden. Somwijlen ook nemen de ouderlijke snavels het hapje in 't vuur hunner voederplicht vän elkaar over, om het een der kuikens voor te houden.

Al spoedig hebben de aanvankelijk ook zonder ouderlijk toedoen instinctmatig' "voor. 't vaderland wegpikkende" kuikens hun pik-reflex volgens het trial-and-error systeem geleerd te beteugelen, èn niet alleen de geoefendheid verkregen om goed-gecoördineerde pik-bewegingen uittevoeren, maar daarbij ook tèvens de door de ouders voorgehouden lekkernijen leeren 
onderscheiden van oneetbare steentjès, strootjes enz. Binnen enkele uren hebben de verworven associaties den instinctieven aanleg in de goede banen geleid, en spoedig ook den cléronomen reflex in dier voege gewijzigd, dat de kuikens den ouders het aangebrachte voer, nog vóór dat deze het konden laten valllen, uit den snavel wegpikken. Na eenige dagen weten ook de kuikens, "waar Abraham den mutsaard haalt", en gaan ze op hun manier ook reeds op voedsel uit, leerend uit allerlei toevallige gunstige en ongunstige ervaring. Ze hebben dan ook het juiste gebruik der hun aangeboren schuwheid en kraanvogelomzichtigheid verkregen. Onbewust van. welk gevaar ook en argeloos "als pasgeboren kinderen": als ze de eerste dagen nog waren, hebben ze nu geleerd hun ouders letterlijk op' den voet te volgen, dier omzichtigheid overgenomen, en niet dan met de grootste moeite mocht het ons, gelukken althans één der kuikens te fotografeeren. Ofschoon ze niet zoo snel als jonge Reigers en Ooievaars groeien, en : er veel langer dan deze nog „donzig” uitzien, hebben ze omstreeks het einde van den zomer toch een flinke grootte bereikt en maken in hun jeugdkleed, dat doffer van toon is als het typische kraanvogelgrijs der ouders, een overwegend bruinachtigen indruk. Dit bruin komt tot stand, doordat de pennae of op het basale gedeelte na geheel bruin, òf van bruine randen voorzien zijn. De schouder- en vleugeldekveeren zijn op grijsblauwen grond van bruine toppen voorzien. De dekveeren aan de keel zijn geelachtig wit; die aan de voorzijde van den hals worden naar onderen toe steeds donkerder tot geelachtig bruin toe. Borst en buik zijn grijsachtig geel; aanvankelijk domineert het geel, maar tengevolge van het in de lengte uitgroeien der geel-omrande doch overigens grauwe veeren, neemt op den duur de grauwe kleur de overhand.

Slag- en stuurpennen zijn donkergrijs, van sierveeren is in zooverre eenigszins sprake, dat de hiertoe in 't volwassen kleed voorbestemde dekveeren reeds een eigenaardigen, verlengden vorm vertoonen.

Omstreeks October vangt een merkwaardige verk leuring aan; doordat de aanvankelijk lichtbruine onderste halsveeren (die later den typischen "witnek" vormen zullen) wit beginnen te worden, terwijl voorts gedurende den winter langzamerhand overal het „kraanvogel-grijs": in 't geverderte de overhand neemt. Deze verkleuring komt neer op een verliezen van de "bruine randen der veeren; gelijk dit ook bij den z.g. .,voorjaarsrui" van velen onzer zangvogels plaats vindt, die zonder een veer te verliezen een bruiloftskleed gaan ver-: toonen, en hierbij door slijtage van hun winterpakje mooier, want volkleuriger worden. De jongen dragen dit opgekleurd jeugdkleed tot deh algemeenen rui, die ze gelijk met de ouders in den volgenden zomer mee-maken. Ze ruien dus alle eerste veeren, de slag- en stuurpennen uitgenomen, op eenjarigen leeftijd.

Het eenjarig kleed verschilt dan alleen in den lichteren toon, het iets duidelijker afgezet wit en den iets meer geprononceerden vorm der toekomstige sierveeren van het "opgekleurde jeugdkleed."

Met den tweeden rui, dus in den derden zomer na hunne geboorte, prijken ze eerst in het volwassen vederkleed; het rood der naakte aangezichtshuid komt ook eerst in het derde jaar - bij het $\sigma^{\prime}$ : sterker dan bij het 으.-, wanneer de vogels: hunne geslachtelijke rijpheid hebben gekregen, op volle kleur en schijnt met de jaren nog aan intensiteit te winnen.

\section{OPMERKINGEN.}

$\therefore \quad$ In tegenstelling tot de ervaring bij ons paar Ardea goliath opgedaan, mocht het nimmer: gelukken de. Witnekkranen tot broeden in hun nachthok te brengen.' Toen in 1916 op 15 Mei noodgedwongen het 1 ste ei binnen moest: worden gelegd, rolden de vogels het zoodra ze. hun kans schoon zagen onmiddellijk naar buiten. Ongelukkigerwijs ging het ei hierbij te loor. Den 18 den werd toen op de gewone plaats bij het water een tweede ei gelegd, op den 20 sten door een windei gevolgd, terwijl op 22 Mei het legsel weer met een normaal ei werd: besloten. Ei 2 en 4 leverden gezonde jongen op. Het legsel van alle Gruidae bestaat echter. normaliter uit " 2, bij hooge uitzondering uit 3 eieren. Het volgend jaar" werd geen legsel 
verkregen, wat echter in verband kon staan met 't feit, dat het $o$, door gedurig regenweer tijdens de broedperiode 1916 te veel aan 't nest gebonden, blijkbaar zeer verzwakt en door rheumatiek bevangen werd.

Uit herhaaldelijk en pertinent weigeren der vogels om binnenshuis te broeden blijkt dat - hoezeer ze ook overigens met hun nachthok vertrouwd waren - toch in zake de keuze eener broedplaats "de natuur bij hen boven de leer ging", de verworven associaties ten opzichte van het nachthok niet bij machte waren het broedinstinct - voor zooverre in betrekking tot een leven onder den blooten hemel, - te wijzigen.

Merkwaardig ook het feit, dat telkenjare de. $\sigma^{1}$ des avonds bij het opsluiten steevast $q$ en jongen vóór laat gaan, terwijl omgekeerd des morgens bij het naar buiten laten der vogels de $\sigma^{7}$ altijd het eerst het perk instapt, . , en jongen achter zich aan latende komen. Vermoedelijk geleid door de ervaring dat binnen niets te duchten valt, terwijl buiten met betrekking tot de buren een oogje in 't zeil moet,worden gehouden.

Opmerkenswaard dunkt ons ook nog het volgende gebeuren:

Toen op 14 Sept. 1917 - dus geruimen tijd na den broedtijd - een in 1916 geboren paar Pseudogeranus leucauchen geplaatst, werd naast een bejaarde Antigone antigone - welke vogel sedert 1904 hier als volwassen exemplaar aanwezig was en nimmer van eenige lust tot broeden had blijkgegeven - legde deze vogel op eens vaderlijke of moederlijke neigingen aan den dag. Niet alleen dat de oude heer (of matrone) voortdurend langs het hek de naast loopende jonge lencauchen lokkend volgde, en hen door de tralies voedsel bracht, maar ook liet deze Antigone - hoewel de broedtijd lang voorbij was - zich op den aanblik der naburige eenjarige vogels nog verleiden tot het maken op eigen terrein van een soort nest met behulp van uit het nachthok bijeengezochte turfmolm en veertjes. Behalve van suxueele instincten zou hier wellicht ook sprake kunnen zijn van eene primitieve verbeeldingskracht, van een "willekeurige fantazie-werking": het simuleeren, buiten alle broedtijd en gepaard zijn om, van ouderzorgen, gevolgd door den toch min of meer gefingeerden aanleg van een nest. Waarbij nog valt op te merken, dat een tweede eveneens bejaarde Antigone, waarmede voornoemde vogel sedert 1904 in volle vrede en vriendschap had geleefd; van nu af aan werd verstooten. Of zich hierin „de gevolgen van kinderloos gebleven huwelijk" openbaarden, dan wel of het plotseling ophouden der goede verstandhouding te wijten viel aan naijver, wellicht ook aan afgeleefdheid...van den ouden perkgenoot konden niet met zekerheid worden vastgesteld.

\section{Catharista atrata. Bartr.}

Van een paar 23 Juni 1901 ingekomen. Zwarte Gieren werd van 1904 af telkens om het jaar, van 1910 af echter jaarlijks een broedsel verkregen, totdat in 1914 het o kwam te sterven. Wellicht wordt ook in de natuur door jongere paren niet geregeld jaarlijks gebroed.

Soms reeds aanvang Mei, de meeste jaren echter eerst omstreeks de laatste helft dier maand of de eerste helft van Juni, zagen wij van $\sigma^{7}$ en $q$ een soortgelijke "trekkebekkende" vrijage, als hier ook van een jong paar Condors kon worden waargenomen.

Als broedtijd mag Mei-Juni worden opgegeven. Het legsel bestaat uit 2 eieren; rondeivormig, $\% 5 \times 50$ m.m., van licht-gele, min of meer naar groen of grauw zweemende grondkleur, bruin en rossig-grijs gevlekt, en vrijwel glansloos en korrelig van schaaloppervlakte.

We vonden de eieren altijd op den zandvloer van 't nachthok, en wel op eene zoo donker mogelijke plaats. Veelal verrolden de vogels hun $1^{\mathrm{e}}$ ei naar een betere plek, waar dan bijgelegd en gebroed werd, meesttijds achter een opengezette deur, zijnde daar de meest donkere gelegenheid. Van nestbouw werd nimmer iets bespeurd.

Deze bij herhaling waargenomen feiten, mede in verband met het verschijnsel dat de pasgeboren kuikens terstond bij vreemde nadering beginnen te blazen, wekte bij mij het vermoeden dat .Catharista een hol-broeder is, 't zij dan dat het legsel in boomholten of wel op den grond tusschen boom-wortels of in ravijn-spleten wordt uitgebroed.

Het reflectorisch blazen der pasgeboren jongen toch mag, zoo goed als het bekende 
„slangengesis" der kuikens van onze Strix flámmea; als een juist holen-broeders zeker in veel gevallen ten goede komend afschrik-instinct beschouwd worden, gezien ook de bekende aangeleerde angst die veel apen en roofdieren voor slangen schijnen te bezitten.

Beide ouders broeden; het $\sigma^{7}$ werd echter overdag gewoonlijk buiten gezien, des ochtends vroeg daarentegen steevast op 't nest aangetroffen, terwijl het $o$ zich dan op haar beurt buiten ophield. Zoodat het $\sigma^{7}$ : bij dag de. wacht houdend des nachts het $\%$ bij 't broeden aflost. Daarentegen draagt alleen het $Q$ - ook 's nachts - zorg voor de verwarming der kuikens, terwijl het $\sigma^{7}$ zoodra de eieren uitgekomen waren, zich buiten ophield, veelal gedurig langs de hekken der buurlieden heenenweerloopend, hoewel er bij de buren door niets hoegenaamd reden werd gegeven om hen van vijandelijkheden jegens het (hun ook trouwens verborgen gebleven) nest te beschuldigen. Door dit doelloos, min of meer steryotyp uitgevoerd worden, verraadt zich deze afweerhandeling van het $\sigma^{\top}$ als zuiver instinctmatig, tevens een goeden grond leverend voor de nog zoo vaak tegengesproken bewering dat er bij instinct - bij cleronome gecompliceerde reflexen dus - volstrekt niet immer en altijd van eene totaal onwillekeurige, onbewuste uitvoering sprake behoeft te zijn, althans niet bij hoogere dieren als Vogels, en tot op zekere hoogte ook de Reptielen zonder twijfel zijn.

$\mathrm{Na}$ een bebroedingstijd van \pm 40 dagen komen er kuikens voor den dag met een inderdaad bijzonder protectief donskleed, van bruinachtig-grijze, min of meer "zandige" kleur en zoo volmaakt met den ondergrond overeenkomend dat, wanneer ze zich na twee weken ongeveer als vrij groote donsjongen geregeld buiten vertoonen, het niet zeer nauwlettend publiek hen totaal over 't hoofd ziet. Ook de bij volwassen vogels naakte huidplekken aan den kop zijn met lang, draderig dons bekleed. Na 6 weken ongeveer komen de eerste zwarte veeren, die, tusschen het zandgele dons overal uitstekend, een allerzonderlingst "slordig" effect geven, en met 3 maanden ongeveer heeft het donskleed voor het je ugd $\mathbf{k} \mathbf{l} \mathbf{e} \mathbf{e} \mathbf{d}$ plaats gemaakt, met dien verstande evenwel, dat van de lange, draderige donsveeren in het aangezicht en tusschen de kopveeren in het volgend jaar Juli nog de duidelijke sporen te vinden zijn.

Met den eersten rui in het e enjarig kle ed dus, verliezen de jongen ook dit laatste uiterlijk zichtbare dons, maar vertoonen toch nog niet de naakte gierenkop-en-hals der ouders, aangezien de toekomstig naakte kop-en-halshuid merkwaardigerwijs bij hen nog met kleine zwarte pennae bevederd is.

Eerst met den rui van het volgend jaar Juni-Juli verliezen ze ook deze zwarte aangezicht-veertjes, en vertoonen ze zich op volle kleur, met den loodblauwen kop en hals der volwassen vogels, kaal tot in de schouderstreek.

Beide ouders voeren, en wel in dier voege dat ze het door hen voorverteerde vleesch op den grond voor de jongen uitbraken, welke het dan terstond - zonder vóórpikken dus opnexnen.

Zoolang het o nog binnen bij de jongen moet blijven - een 14 dagen zoogezegd verloopen eer deze zich met de moeder buiten vertoonen - brengt voor zoover wij konden waarnemen het $\sigma^{\gamma}$ haar geen voedsel, maar liep het $q$ met den voertijd even van de jongen weg om haar portie te halen.

De jongen werden tegen den volgenden paartijd - als eenjarige vogels dus - door de ouders afgebeten en weggejaagd.

\section{OPMERKING.}

Het feit, dat onze zwarte Gieren in het jeugd- zoowel als in het eenjarig kleed nog niet de naakte kop-. en halshuid der ouders te zien geven, maar dat de donsveeren daar ter plaatse in het eenjarig kleed vervangen worden door bijzondere, bij de volwassen vogels absoluut ontbrekende, pennae, komt mij zeer merkwaardig voor.

In verband met de wetenschap, dat we in jeugd- en éenjarig kleed - voor zooverre althans niet sprake is van eenige moderne acquisitie op het jeugdleven betrekking hebbende, zooals dit b.v. bij vele "larvale organen" der Amphibien het geval is - een primitieven 
toestảnd mogen zien, en voorts ook: in verband met het verschijnsel dat de Maraboe's, die - kadaver-verslinders als ze zijn - geacht mogen worden onder de Ooievaars een soort-: gelijke plaats in te nemen als de Gieren onder de Roofvogels, eveneens kale koppen en halzen vertoonen in 't volwassen kleed, moge hier de onderstelling worden geopperd, dat bij Gieren zoowel als bij. Maraboe's, bij de kaalkoppige en kaalhalzige vormen onder Roofrogels en Ooievaarsachtigen dus, de naakte kop- en halshuid een moderne. acquisitie zoù kunnen zijn, te beschouwen als eene aanpassing aan de bijzondere voedingswijze. Bij het rondsnavelen in kadavers toch, zouden bevederde koppen en halzen onbruikbaar zijn; terwijl de naakte vettige huid der Gieren- en Maraboekoppen en halzen zich gemakkelijk weder van bloed en weivocht laat reinigen. Wellicht hebben de genoemde Vogels dan ook b.v. langs den weg van selectie eener in dit opzicht nuttige variatie, of op welke wijze ook, hunne doelmatige naakte koppen en halzen, zoo bruikbaar bij hun gewone aas-etersbedrijf, verkregen. 


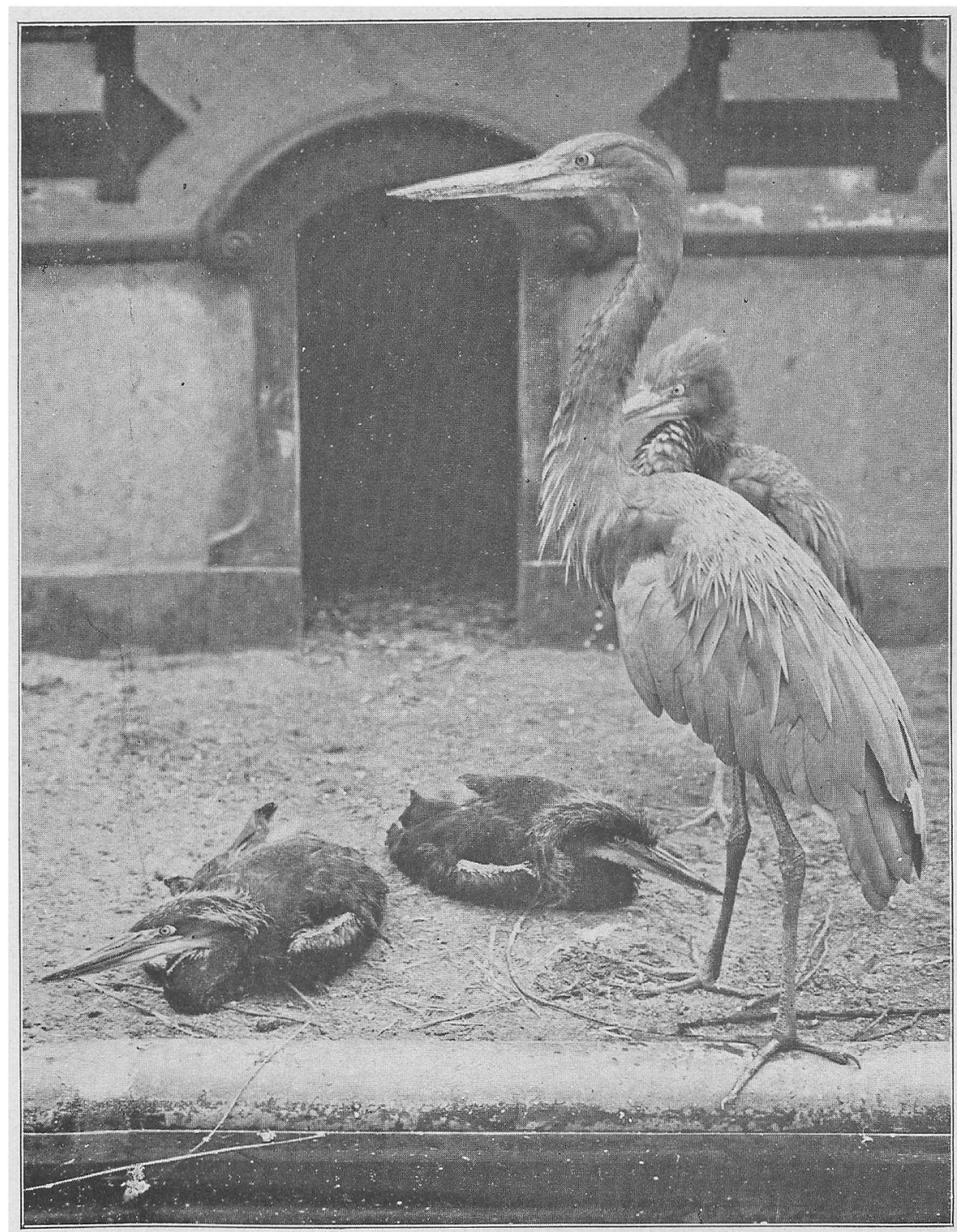

Paar Ardea goliath Cretschm. met +6 weken oude jongen in drie-weeksch jeugdkleed. Phot. A. J. W. de Veer.

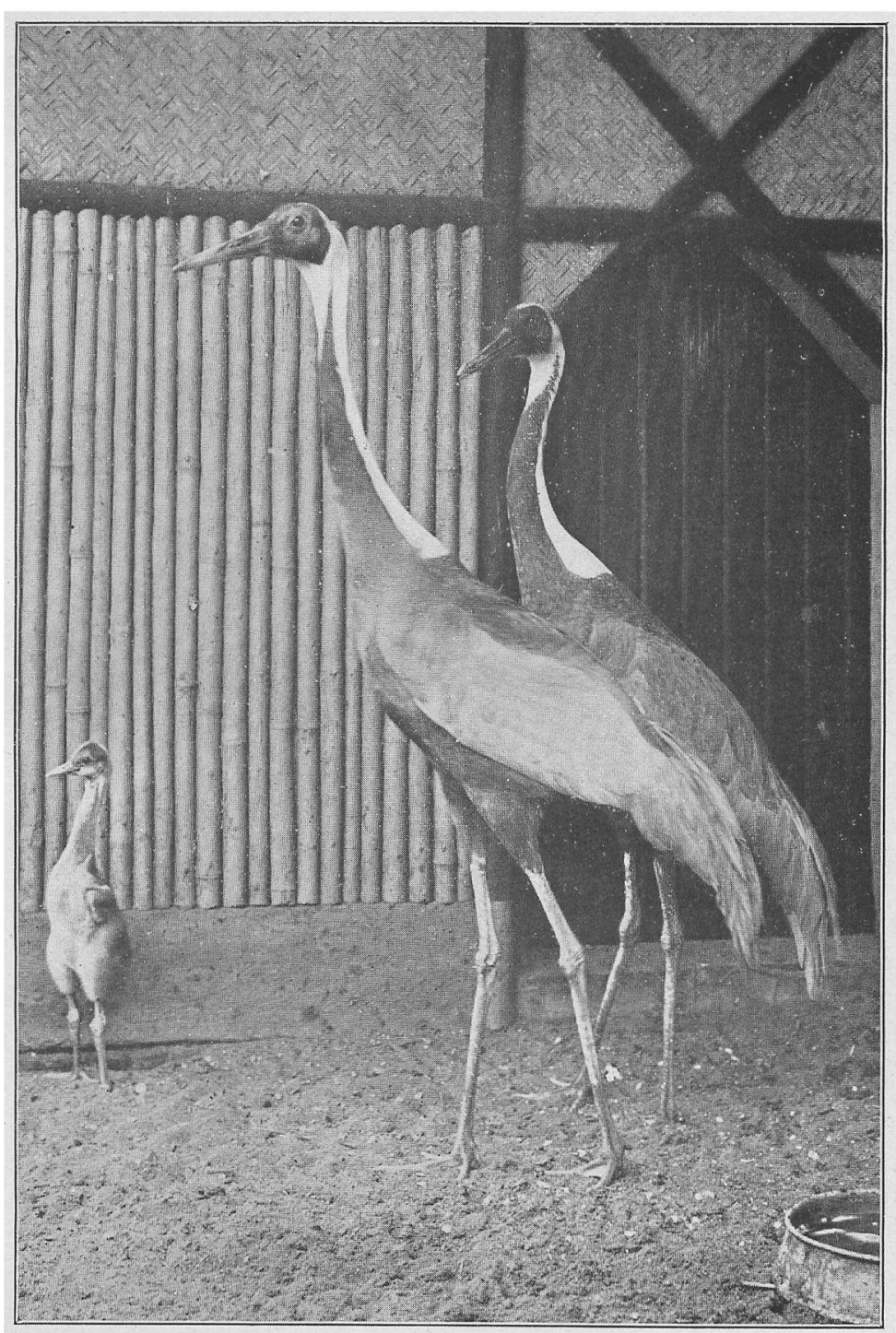

Paar Pseudogeranus leucauchen Temm. met kuiken van 14 dagen in donskleed. Phot. A. J. W. de Veer.

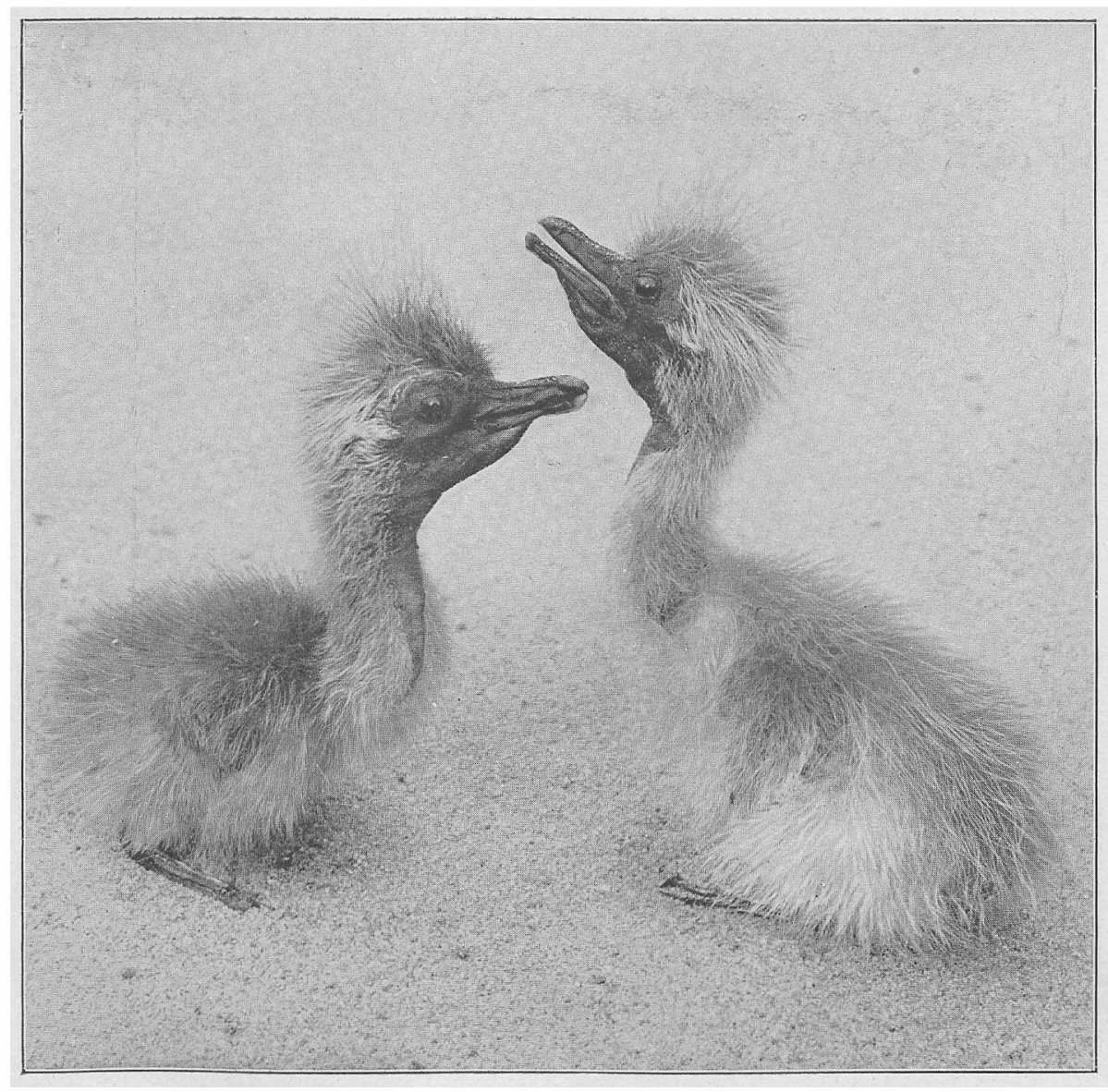

Kuikens van Ardea goliath Cretschm. 6 dagen oud.

Phot. P. L. Steenhuizen.

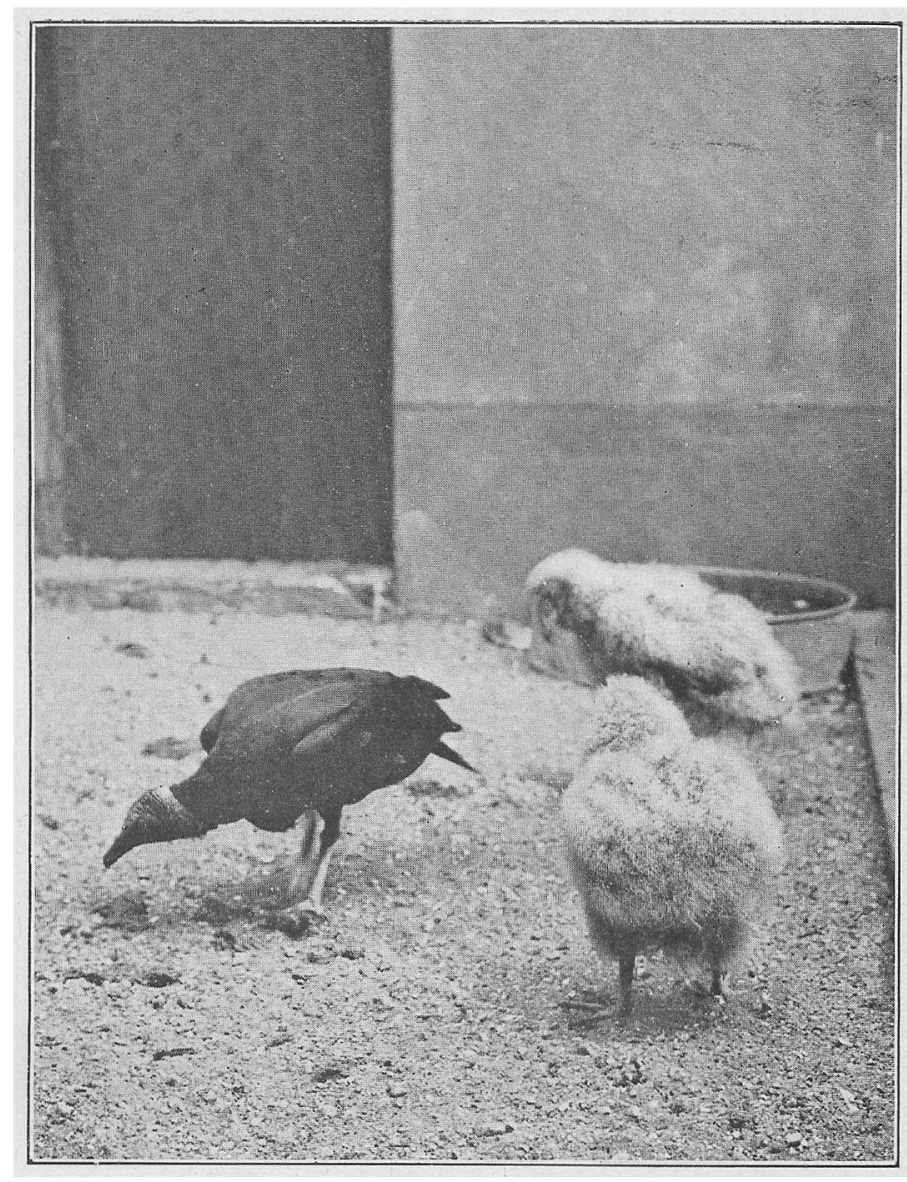

Catharista atrata Bartr. o met kuikens van 6 weken in donskleed. Phot. A.J.W. de Veer, 